\title{
Toward an Anti-Racist and Anti-Colonial Post-Internet Curriculum in Digital Art Education
}

\author{
Timothy J. Smith
}

This chapter explores the ways in which teaching post-internet in digital art curriculum can be reframed through the lenses of anti-racist and anticolonial approaches. Practices and discourses around art and technology have suffered from a lack of inclusion and equity, which extends from the racist and colonial history that undergirds the arts and education (Drew, 2015; Valentine, 2015). Anti-racist and anti-colonial approaches offer a framework for critically analyzing identity, ideology, and power relations through art education, and for fostering active socio-political engagement in the world through transformative artist practices. This article bridges this framework with post-internet art in digital art curriculum through an examination of the work of artist Tabita Rezaire, whose practice analyzes White supremacy and colonialism. As such, this article endeavors to build a pedagogical foundation toward teaching post-internet in digital art

\footnotetext{
T. J. Smith $(\bowtie)$

University Wide Art Studies, Aalto University, Espoo, Finland e-mail: tim.smith@aalto.fi

(C) The Author(s) 2021

K. Tavin et al. (eds.), Post-Digital, Post-Internet Art and Education, Palgrave Studies in Educational Futures, https://doi.org/10.1007/978-3-030-73770-2_14
} 
curriculum within the discourses and practices of anti-racism and anticolonialism. It is primarily presented through a radical restructuring of my own curriculum development as a teacher of introductory university courses focusing on digital art. While this chapter discusses my experience with university teaching, the overall pedagogical framework is intended to be presented in a way that allows its concepts and discourses to be adapted to various educational settings, from K-12 education to upper level university special topics courses.

\section{The Problem of Mainstream Post-Internet Art}

Quaranta (2015) positions post-internet discourse in contemporary art emerging in the late 2000 s as "a cultural reference, and an environment, rather than a medium" (p. 125). Archey and Peckham (2014) situate post-internet artistic practice as "an internet state of mind [which] describes an art object created with a consciousness of the networks within which it exists, from conception and production to dissemination and reception" (p. 8). Drew (2015) similarly discusses internet and digital culture as opening a new landscape of art, but significantly frames it within a context of social justice:

As we embark on the new landscape, it's imperative that we labor to create a new biology that is as diverse and equitable as possible. I hope their words help spark conversations about representation, erasure, and the future of digital art. (para. 5)

This assessment on the landscape of internet and digital culture in art is echoed by many commenters who are critical of mainstream postinternet art-albeit with a less hopeful prognosis—citing it as a marketable aesthetic style produced by artists from mostly similar geographic and socio-economic backgrounds. As Chan (2015) observes, "the art world is a white frat house, and most post-internet discussion has been between the academically clustered internet art communities in North America and Western Europe" (p. 120). Post-internet artists tend to share a sensibility that Quaintance (2015) elaborates as "the intellectual construct of a homogeneous in-group-mostly concentrated in the narrow western geographical bases of London, New York and Berlin-whose members share extremely similar linguistic frameworks, values, lifestyles, behavioral norms and class affiliations" (p. 7). These observations coincide with what 
I have viewed as crucially lacking on the whole in the most prevalent responses from artists to the impact of internet and network cultures.

Much of the aesthetic of post-internet art is steeped in nostalgia of youthful online surfing - particularly of 1990s graphics and software such as MS Paint and Geocities web design-recalling the luxury of time spent exploring the uncharted World Wide Web as children of the late twentieth century. Now, as adults, post-internet artists ride that nostalgia as it reflects the tendency (and inherent privilege) to indulge in the banality of browsing online in the twenty-first century. As Droitcour (2014a) suggests, many post-internet artists "begin with the proposition that the phenomena of their world are boring and banal, who begin with an exasperated sigh" (para. 10). In this sense, such artistic practices are often less about grappling with the socio-political implications of the post-internet conditionand more about presenting superficial and self-referential explorations of the experience of white, Western, middle-class artists in the internet age (Blas, 2014). Another observation of post-internet art is in its appeal to the art market through its ennui-laden aesthetic style that is presented more often as an art world inside joke, or as Droitcour (2014b) frames it, "art about the presentation of art" (p. 118). Blas (2014) similarly articulates what makes post-internet art appealing to the art market is that "its neutral frame provides a safe, hollow concept to fill, which corrupts the very political potential of aesthetics, as what can intervene and shift conditions of life towards equality, not capital" (p. 88).

While I certainly agree with these critiques focusing on how much of the post-internet art that has gained mainstream art market attention generally suffers from these patterns of what Quaintance (2015) refers to as "commercialism, juvenilia, narcissism, superficiality, sociopathy and rampant objectification" (p. 7), I find the narrow positioning of postinternet art in these commentaries also exposes some of the limitations of these arguments. The attributes of the artists that are often the target of these critiques are the chosen few who come up repeatedly as quintessential representatives of mainstream post-internet art. My intention is to look beyond the select few art-world-approved exemplars of post-internet artists to locate viable socio-political potential of artists creating work responding to the internet and network cultures. In other words, what is needed is an expansion of the discussion of post-internet art that includes narratives beyond those that are overwhelmingly told from the perspectives of artists who are White, Western, upper-middle-class, and identify as male. 
I contend that to deploy its potential as a platform for reconsidering the canon of digital art and art education, post-internet can be reframed to become not only more inclusive, but the socio-political themes raised through its expansion can also generate openings toward that new landscape of network and digital cultures in art that actively engages anti-racist and anti-colonial perspectives. Furthermore, I contend that this discourse must take shape through those who are educating contemporary artists and art educators in the post-internet age-particularly in teaching digital art. This starts with a reframing of curriculum development that approaches teaching post-internet in digital art through the lens of anti-racist and anti-colonial approaches.

\section{Reflections on Digital Art Curriculum Development}

One of the primary reasons as to why I have felt compelled to write this article stems from a reflective inquiry into my own biases as an educator. I have taught art at the university level for the past decade, with a primary focus on art foundations and introductory general education courses in digital art. The two significant components of the curriculum of these courses have been (1) to teach basic skills and techniques of digital software and hardware, and (2) to articulate and cultivate critical discussion surrounding the uses of digital technology through historical and contemporary art and culture. While much could be said about the methods of teaching the actual skills and techniques of digital tools, due to the limitations of the scope of this article, I will focus strictly on the critical discussion component of my course curriculum.

As I look back at a snapshot of my digital art curriculum when I first developed it ten years ago, I tallied 62 artists and theorists that were mentioned as part of my lectures or as part of the texts and online resources that I assigned to the students for the first two semesters. Of that total, ten were women (16\%); four were artists of color $(6 \%)$; six were based in countries outside of the United States or Western Europe (10\%); and two were based in the Global South (3\%). While the artists and authors that I discussed with my classes were derived from a recommended list of artists and texts from the department, I was ultimately responsible for the selections that I included in my curriculum. Significantly, this also echoed a very similar pattern of exclusion in prominent survey texts focusing on digital art and new media art (Greene, 2004; 
Paul, 2003; Rush, 2005; Tribe \& Jana, 2006). It speaks to the significance of mainstream practices and discourses within art and technology as overwhelmingly exclusive to the study of White, Western, mostly male-identifying artists and scholars.

Through my dedication to teaching visual culture art education (Duncum 2003; Freedman, 2003; Tavin, 2003) and critical media literacy (Kellner \& Share, 2005), there have always been at least some sections in my digital art curriculum that have explored and analyzed race. However, I very rarely turned to artists of color as examples from new media and digital art, specifically because to my knowledge they did not exist in the mainstream canon of these genres. Instead when discussing race in my digital arts courses, I would focus on images and videos from the media and popular culture to analyze with the students in class. As a point of contrast, when we discussed topics such as gender or climate change in my digital art courses, I always had examples of feminist artists and environmental artists that I could turn to from the mainstream new media and digital art canon. Without examples of the practices of artists of color, I was bypassing the very voices that serve as exemplars to students as originators and navigators of possible futures.

In the summer of 2014, I was deeply affected as I witnessed the mainstream rise of the Black Lives Matter movement, and I was compelled to delve deeper into understanding the long history of systematic racism and racially motivated violence against Black people in the United States. I was concurrently motivated to overhaul my digital art curriculum beginning that autumn to include more nuanced and complex discussions about race. However, as race began to play a more prominent role in my curriculum development, it became apparent that there was a glaring lack of representation of artists of color in my course content. This led me to consider other gaps in my curriculum development, particularly regarding the lack of inclusion of artists from the Global South. In 2016, I began teaching at Aalto University in Finland, where it was imperative for me to expand my curriculum development to include artists and themes from the Nordic region. I realized that if I could put so much work into broadening my curriculum to include Nordic artists simply because I was teaching in a Nordic country, I could certainly afford to put the time and effort into expanding content to include artists and themes from the Global South. Incidentally, this global shift in my digital art curriculum development was bolstered through enriching and rewarding conversations with the many international students at Aalto University who had 
urged me to engage non-Western epistemologies, art canons, and artist practices in my course offerings.

From a personal perspective, this process of change has required me to analyze my own blind spots over the past decade as I consistently avoided discussing and analyzing the work of artists of color or artists from the Global South in my digital art curriculum. As I examine the ways in which I continued to reinforce the status quo, I recall that my intention for doing so was a matter of seeking to avoid complicating the digital art canon. My rationale at the time was that since I was a White teacher in the United States, I figured it was not up to me to attempt to challenge the homogenous list of artists and theorists that were being handed down to me from my professors and prominent art historians. This glaringly demonstrates my privilege of actually being afforded the choice to avoid confronting racism and colonialism in the art canon. It exposes the violence of White supremacy and Eurocentrism that I have upheld through exclusion and negation of the voices of marginalized artists in developing my curriculum for digital art. It was harmful enough that I felt that it wasn't important for me to personally engage in selfreflective analysis of my curriculum development. What made it far more damaging was that my inaction affected the learning of a new generation of student-artists who were implicitly being taught that these topics didn't have to matter for them either. Because the mainstream historical and contemporary discourses of digital and new media art have been almost entirely focused on White, Western, male-identifying artists, and scholars, it requires a deeper dive for teachers to move beyond the accepted survey texts and established curricula. Several years into maintaining that status quo of negation through my teaching of digital art, it became clear that it was vital for me to do my part in actively taking steps to reconcile my teaching of these courses that had previously side-stepped social justice and critical methodologies.

\section{Decentering the Art and Technology Canon}

In my restructured curriculum development, anti-racist and anti-colonial approaches now serve as the core framework for teaching post-internet in digital art courses. Colonialism exists today through the continual self-validation of White and Eurocentric knowledge and histories as the universal system of knowledge production and maintenance (Mignolo, 2000). In this sense, Western knowledge is perceived not just as the 
dominant system of knowledge, but it is presented as the only system of knowledge, which thus invalidates and excludes histories, narratives, and lived experiences of those who do not fit into its regime.

Global White supremacy is inherently entwined with the continuing legacy of Eurocentrism, and is methodically enacted through the social construction of race as a tool of power and control (Sefa Dei \& McDermott, 2014). Harris (1993) articulated the concept of White property as the unquestioned claim of ownership and domination through the exploitation and erasure of Black people, Indigenous people, and people of color (BIPOC): "Whites have come to expect and rely on these benefits, and over time these expectations have been affirmed, legitimated, and protected by the law" (p. 1713). As such, this notion of White property thoroughly pervades the political, economic, legal, and educational systems in societies afflicted by colonialism and White supremacy. Educational institutions perpetuate racial domination through a two-pronged approach of oppression: first, through rendering invisible the history and continued policies and structures of colonial violence and racism; and second, through the exclusion and effacement of BIPOC histories and lived experiences (De Lissovoy \& Brown, 2013).

Anti-racist and anti-colonial discourses and practices challenge the assumed universalization of White and Eurocentric knowledge production. They mobilize as practices of resistance to oppressive colonial and racist power relations, and embrace local and situated knowledges that serve as counter-narratives to the dominant White and Eurocentric regimes of knowledge. In the context of art education, one crucial way in which anti-racist and anti-colonial approaches influence curriculum development is by qualitatively shifting the Western art canon toward transnational perspectives, and is particularly inclusive in its attention to the practices of BIPOC artists. Art history and art education often perpetuate the curricular oppression that excludes non-White and nonWestern narratives, or renders them to the margins (Iskin, 2017). Gayed and Angus (2018) point to decentering as a curricular positioning that disrupts the Eurocentric art canon as to "determine a historical narrative that does not 'other' non-Western art as periphery, derivative, or reduce it to an addendum to dominant history" (p. 232).

Decentering the canon is a qualitative process insofar as it moves beyond a simple additive insertion of BIPOC artists into the curriculum. An "additive approach" to disrupting the art canon fails to address how White supremacy and colonialism is embedded in the arts and art 
education (Knight, 2006a, p. 41). Instead, curriculum development must engage at the outset in what Knight (2006a) calls a "transformational approach" that moves beyond a quantitative inclusion of content, such that "the art teacher seeks to change the structure of the curriculum to enable students to view matters from the perspectives of 'the Other" (p. 41). In this form of teaching and learning, inclusion is not a token gesture toward a liberal conception of diversity, such as devoting an isolated week or month for including BIPOC artists, or discussing their work without addressing underlying structural contexts of White supremacy and colonialism in the arts and art education. Rather, as Acuff (2013) argues, the curriculum itself is qualitatively changed when the content of the course involves critical discussion and reflection that focuses on creating conditions through which students have "questioned power structures, identified personal biases, promoted equity, and learned empathy" (p. 83).

While it is vital to open up candid, critical dialogue about racism and colonialism in the classroom, this is only a first step toward critical transformation for students. Here, Knight's (2006a) "social action approach" (p. 41) to curriculum development becomes essential in activating a critical transformational practice, insofar as it expands on qualitatively changing the structure of curriculum by focusing on furthering the "attitudes, knowledge, and skills necessary to participate in social change." (p. 4l). As such, the intention for decentering the canon moves beyond solely engaging in critical discussions in the classroom, and toward the overarching goal of cultivating a critical transformation in students' engagement outside of the classroom, particularly through the active deployment of criticality their practices as artists in the world.

The social action approach puts the curriculum to work by opening spaces for students to engage in a deep-dive of self-reflection by extending their critical position toward activating a transformational artistic practice. Anti-racist and anti-colonial methods play pivotal roles in this process, as they embolden students to reckon with questions of power relations, identity, and privilege imbued in the act and process of transformational artmaking. They offer pause for students to consider questions such as: "what is the content and subject matter being conveyed through my work? Is that content and subject matter perpetuating white supremacist and colonial narratives, or is it actively occupying an anti-racist and anti-colonial critical position?”. 
When working with White, Western students in cultivating a transformational artist practice, the focus should not solely dwell on negation in one's practice. Such negation would include avoiding appropriating BIPOC visual culture, and particularly images depicting BIPOC violence and suffering (Black, 2017). One of the objectives of deploying anti-racist and anti-colonial methods in art education is to facilitate the cultivation of critical tools with which students are able to proactively recognize and understand why the misguided formal and thematic choices some artists make in their artist practice, such as cultural appropriation, perpetuate racial and colonial violence. Rather than being preoccupied with avoiding content and subject matter, the intention of both the transformational approach and social action approach to curriculum development is to build a learning environment in which an affirmative engagement with artmaking emerges that actively expresses an anti-racist and anti-colonial critical position. One way to explore how this critical engagement through artmaking could take form in an artist practice is to examine the ways in which artists have activated these conceptual underpinnings through their work. The next section of this article will explore an example of an artist who demonstrates this mobilization of an anti-racist and anticolonial positioning into an active mode of critique through a sustained artist practice.

\section{Anti-Racist and Anti-Colonial Decentering in Tabita Rezaire's Artist Practice}

One of the many artists I have been working into teaching post-internet in my restructured digital art curriculum is French Guyana-based Tabita Rezaire, whose video and virtual reality artworks tap into the politics of technology and online practices, and serve as modes of anti-racist and anti-colonial methods for education and decentering the canon of Western hegemonic narratives. Her work, Sorry for Real (2015), depicts a hovering virtual iPhone displaying its caller ID as "Western World," in which an ongoing (one-sided) call depicts a computerized, Americanaccented, male voice offering a series of apologies on behalf of the West. The 17-min-long monologue systematically articulates the myriad ways in which the tenets of colonialism and White supremacy have subjugated, exploited, and oppressed the societies, cultures, and lands of the Global South over the centuries, and continue to do so in the contemporary world. Throughout the monologue, a series of SMS dialogue text bubbles 
pop up around the floating iPhone as a running commentary between two women who are highly skeptical of the intentions of the caller: "????... WTF... SOME KIND OF WESTERN SAVIOUR SHIT?”.

The caller's words appear to depict such a keen hyper-awareness of his own White supremacy that it feels implausible that it could be spoken from a White man from the West, which they are not; the words of the monologue given by Western World are conceived by Rezaire. This is why the concurrent SMS text dialogue portrays such suspicion and derision toward the apologies being offered by Western World, to the point where the text commentary seems as if one woman is warning the other about an untrustworthy lover: "He's playing you babe!... Watch out for their side-eye agenda! im telling $\mathrm{u}$ ! (sic)!" But they are both aware that it is not just a scheming boyfriend on the other end of the phone. Instead it is the monotone, matter of fact voice of a man appearing to say all the right things in his apology for the centuries of atrocities on behalf of the West, which the participants in the SMS chat are able to clearly see through: "THANKS FOR THE SPEECH BUT ... WE ARE BEYOND THE NEED FOR AN APOLOGY... WE NEED YOU TO STOP BEING ENTITLED!!" Here Rezaire's work clearly speaks to the lip-service, in which an acknowledgment of wrongs and an apology is considered to be enough for the West, but crucially the status quo of White supremacist and colonialist legacies persists.

Sorry for Real (2015) is an example of an artist decentering White supremacist and colonial hegemony. Rezaire achieves this by rendering the voice of the Western World inert within the interface of the video. As the monotone voice drones on throughout the phone call, its unconcerned tone and cadence is in effect drowned out by the compelling incredulity of the women's SMS chat and the heightened visuality of their animated text bubbles eagerly populating around the floating iPhone. Rezaire's choice to use a computerized voice for the Western World creates a distancing effect for the viewer. The resonance of this voice evokes a disingenuous politician reading a speech that he did not write, or did not even consider reading before delivering it. Through Rezaire's formal choice in presenting such a striking tonal contrast between the monologue and the text dialogue, the video's interface draws the attention of the viewer toward the urgent and distrustful text bubbles, while relegating the prosaic and faithless apology from Western World to the margins. 
Rezaire's multi-modal digital artworks demonstrate the tremendous potential for engagement between anti-racist and anti-colonial methodologies in education and post-internet practices. Martini (2017) highlights the artistic practice of Rezaire, among other post-internet artists in her blog titled Decolonizing Technology: A Reading List. Working within the premise of pervasive digital colonialism, the blog's introduction offers a mapping toward approaching technology as a mode of decolonial resistance, anchored by the question: "what does it mean to think about digital technology as a tool to resist and fight against colonial inequality and erasure" (Martini, 2017, para. 19). This contains the resources of a decolonial reading list spanning seminal texts, such as Frantz Fanon's The Wretched of the Earth (1961), as well as contemporary collections such as Worlds \& Knowledges Otherwise (WKO) (2004), which is an online dossier of essays hosted by Duke University's Center for Global Studies and the Humanities. One of the WKO collections is titled Decolonizing the Digital/Digital Decolonization, which includes work from anti-racist and anti-colonial artists and writers that "elucidate how the terms of engagement are being defined, the borders being constructed or crossed, as discursive arrangements of the digital world are contested and refigured" (World \& Knowledges Otherwise, 2009, para. 1).

In an introductory essay for the first volume of Decolonizing the Digital/Digital Decolonization, Benfield (2017) notes the fluid status of the digital, in which "multiple sites of criss-crossing colonial wounds, film, video and new media producers, including artists, scholars, community organizers and popular educators, are creating inter-textual and intercultural works that reorganize the geopolitics of knowledge" (para. 5). In this sense, as Benfield (2017) articulates, the intersection of antiracist, anti-colonial, and digital art practices (including post-internet art), becomes a "site of an/other thinking" (para. 3), following Mignolo's (2000) assertion that decoloniality is a site that can "change the terms, not just the content of the conversation" (p. 70).

Rezaire's overall artist practice is an ideal entry point into entwining these ideas of anti-racist and anti-colonial methods with building critical discourses in the digital art classroom. Her artistic vision extends this decolonial move to change the terms of the conversation through her depiction of the colonial line that demarcates the global digital divide, which in her words, "reproduces oppression and inequality; from racism, misogyny and homophobia to economic and racial exclusion" (cited in King, 2018, para. 17). This includes the physical infrastructure of the 
internet, as explored in her video work Deep Down Tidal (2017), which foregrounds the physical fiber-optic cables laid under the Atlantic Ocean along the same passage as the transatlantic slave trade route. As Rezaire asserts, "the architecture of the internet is based on pain" (cited in King, 2018, para. 16). In response to this pain, she turns to art as a "healing technology," which opens up a "way to 'unlearn': to peel off the layers of this coercive history" (cited in King, 2018, para. 12). In this sense, Rezaire's own unlearning through art as a form of healing can become a powerful beacon for not only decentering the dominant canons of art and technology, but also as a mode of unlearning cultivated through decentering curriculum that actively critiques White supremacist and Eurocentric ideology, identity, and power relations.

Deep Down Tidal (2017) offers a vehicle for Rezaire to raise vital questions about the illusion of the narrative of digital technology and network culture as a single universal cultural condition in which postinternet discourses only articulate its effects on economically wealthy societies. This is often demonstrated by what Sundberg (2014) refers to as "universalizing performances" (p. 36) that are always silent about the "loci of enunciation" (Mignolo, 2009, p. 161) when referring to generalizing narratives framed as having an effect on "us." When postinternet discourse is positioned this way, it is silent in acknowledging that it speaks only to particular cultural perspectives. Only $51.2 \%$ of the world has logged onto the internet, and in lower- and middle-income societies that do have internet access, $57 \%$ of the population log on only through handheld mobile devices (State of Broadband Report, 2019, p. 2). This is due to the extraordinary rates for even the slowest broadband speeds in low income economies - often as much as 12 times more expensive per month than in the United States (Ward, 2011). Even more portentous is the effect of the lack of internet accessibility and control that Kwet (2019) refers to as "digital colonialism," which continues the Eurocentric colonial legacy as a "structural form of domination exercised through the centralized ownership and control of the three core pillars of the digital ecosystem: software, hardware, and network connectivity" (p. 4). In this respect, foreign governments and corporations build the infrastructure and digital technology that "allows them to accumulate profits from revenues derived from rent (in the form of intellectual property or access to infrastructure) and surveillance (in the form of Big Data)" (Kwet, 2019, p. 8). 
In my restructured digital art curriculum, all of the above threads of inquiry that arise when examining Rezaire's work serve as critical resources for deep-dive discussions in the classroom, and are further bolstered by assigned passages from select readings on the themes of race, colonialism, technology, and network cultures. Specifically, Benjamin (2019a, b), Everett (2009), Nakamura and Chow-White (2012), Shifman (2014), and Umoja et al. (2012) offer key interdisciplinary understandings beyond the arts into how digital technologies generate assumptions and perceptions about race. This weaving of different forms of textual resources not only serves to foster more complex, critical readings into locating power structures and personal biases, but it also highlights the flexibility of pedagogical materials in the post-internet age. In this respect, textual resources utilized in course curricula can refer to a variety of digital materials such as artists' websites and social media feeds, online videos, art journals and magazines, academic journal PDFs, and eBooks. Building a curriculum that critically engages the content and subject matter of the work of an artist like Rezaire, and many other artists working toward deconstructing the power relations embedded in technology and digital culture, offers insight into the ways that artists challenge and traverse dominant narratives through post-internet art practices. Cultivating a curriculum that is qualitatively restructured with anti-racist and anti-colonial methods throughout demonstrates a dedication toward disrupting hegemonic messages in media, art, and culture, and generates the fluid groundwork for approaching justice-based narratives through art and digital network cultures.

\section{CONCLUSION}

In her essay "Whiteness Must Undo Itself to Make Way for the Truly Radical Turn in Contemporary Culture," artist Xaviera Simmons (2019) calls for a paradigm shift toward what she frames as "white radicality" in the arts: "If radical change is truly desired in such a place, then those who have the bounty of privilege should shoulder the greater risk, and should be willing to transform, divest of or spend such privilege by all methods available" (para. 3). Similarly, Wolfgang (2019) asserts that educators must seize the

opportunity to acknowledge how legacies of racism and violence continue to deeply impact curriculum and pedagogy in the arts; to make space where 
we have failed in the past; and to reconsider pedagogy as a step toward reparation or mitigating the effects of white supremacy in Art Education on our students, our colleagues, and our communities. (p. 15)

In the context of this chapter, this transformative push begins with how digital art curriculum is presented to student artists and art educators. As a White, male educator from the West, I endeavor to take up Simmons' (2019) insistence on white radicality in the arts, and I commit to Wolfgang's (2019) charge for art education as a space for dismantling White supremacy.

The deployment of anti-racist and anti-colonial approaches throughout a qualitatively restructured digital art curriculum moves beyond a simplistic additive inclusion of content, and actively engages critical analysis and reflection by dissecting relations of power and ideology inherent in digital technology and network cultures. This framework has allowed me to take crucial steps toward correcting my own previous failures of adhering to inequitable curriculum development in my digital art courses. More importantly, it has forced me to reckon with how I uphold my own White supremacist and Eurocentric practices as a teacher, and how I must actively work toward the ongoing process of committing to anti-racist and anti-colonial approaches through teaching and learning. It follows Knight's (2006b) appeal for an art education that is focused as much on critical self-reflection of educators as it is for the students: "An art teacher who is able to deconstruct his or her own Whiteness is in a better position to challenge Eurocentric perspectives and dismantle White privilege" (p. 328). This process of cultivating anti-racist and anti-colonial teacher education is paramount for teachers to lead by example in the classroom, which builds the framework for students to generate their own critical consciousness in learning and artmaking through a digital art curriculum.

In order to create the conditions for reframing digital art curriculum toward anti-racist and anti-colonial methods, the historical and contemporary canon of art and technology must be reevaluated to decenter dominant practices and narratives in art and art education. Despite its relative lack of political engagement in its mainstream form, post-internet art discourse inherently carries the potential to open such counterhegemonic narratives and practices. The incorporation of self-learning, crowdsourcing, and disruptive modes of production, post-production, distribution, and circulation are primary to the practices of post-internet art, and these modes have the capacity to be reoriented to become tools 
for societal change (Smith, 2018, 2020). As a cultural condition, postinternet addresses a wide variety of societal and technological themes ranging from the construction of subjectivity and performance of identity, to surveillance and corporate control (Clark, 2018). As such, these themes are also ripe for decentering hegemonic practices and narratives by reframing post-internet art and its discourses toward anti-racist and anticolonial methods. This lens implores art educators to acknowledge and address deeper critical contexts by confronting head on the Whiteness and Eurocentrism of the canon art and technology and post-internet art, thus laying the groundwork for opening critical transformative practices of teaching, learning, and artmaking in digital art curriculum.

\section{REFERENCES}

Acuff, J. B. (2013). "How will you do this?" Infusing multiculturalism throughout art teacher education programs. Journal of Cultural Research in Art Education, 30, 83-102.

Archey, K., \& Peckham, R. (2014). Essay. In K. Archey \& R. Peckham (Eds.), Art post internet, (pp. 7-24). Ullens Center for Contemporary Art.

Benfield, D. M. (2017, September 18). Introductory Notes. Worlds \& knowledges otherwise. https://globalstudies.trinity.duke.edu/projects/wko-digital-1.

Benjamin, R. (2019a). Captivating technology: Race, carceral technoscience, and liberatory imagination in everyday life. Duke University Press.

Benjamin, R. (2019b). Race after technology: Abolitionist tools for the new Jim Code. Polity Press.

Black, H. (2017, March). Hannah Black's letter to the Whitney Biennial's curators: Dana Schutz painting "must go". e-flux conversations. https:// conversations.e-flux.com/t/hannah-blacks-letter-to-the-whitney-biennials-cur ators-dana-schutz-painting-must-go/6287

Blas, Z. (2014). Contra-internet aesthetics. In O. Kholeif (Ed.), You are here: Art after the internet (pp. 86-97). Cornerhouse.

Chan, J. (2015). Notes on post-internet. In O. Kholeif (Ed.), You are here: Art after the internet (pp. 106-123). Cornerhouse.

Clark, T. (2018). Post Internet. In R. Braidotti \& M. Hlavajova (Eds.), Posthuman glossary (pp. 326-329). Bloomsbury Academic.

De Lissovoy, N., \& Brown, A. L. (2013). Antiracist solidarity in critical education: Contemporary problems and possibilities. The Urban Review, 45, $529-560$.

Drew, K. (2015). Toward a new digital landscape. https://walkerart.org/mag azine/equity-representation-future-digital-art. 
Droitcour, B. (2014a). Why I hate post-internet art. https://culturetwo.wordpr ess.com/2014/03/31/why-i-hate-post-internet-art/.

Droitcour, B. (2014b). The perils of post-internet. Art in America, 102(10), $110-119$.

Duncum, P. (2003). The theories and practices of visual culture in art education. Education Policy Review, 105(2), 18-25.

Everett, A. (2009). Digital diaspora: A race for cyberspace. State University of New York Press.

Freedman, K. (2003). Teaching visual culture: Curriculum, aesthetics, and the social life of art. Teachers College Press.

Gayad, A., \& Angus, S. (2018). Visual pedagogies: Decolonizing and decentering the history of photography. Studies in Art Education, 59(3), 228-242. https://doi.org/10.1080/00393541.2018.1479823.

Greene, R. (2004). Internet art. Thames \& Hudson.

Harris, C. I. (1993). Whiteness as property. Harvard Law Review, 106(8), 17071791.

Iskin, R. E. (Ed.). (2017). Re-envisioning the contemporary art canon: Perspectives in a global world. Routledge.

Kellner, D. \& Share, J. (2005). Toward critical media literacy: Core concepts, debates, organizations, and policy. Discourse: Studies in the Cultural Politics of Education, 26(3), 369-386.

King, A. (2018, February 1). Feel like a cyber slave? Meet Tabita Rezaire, healer of souls: Beyond Afrofuturism. Huck Magazine. https://www.huckmag.com/ art-and-culture/decolonising-the-internet-artist-tabita-rezaire/.

Knight, W. B. (2006). Using contemporary art to challenge cultural values, beliefs, and assumptions. Art Education, 59(4), 39-45. https://doi.org/10. 1080/00043125.2006.11651602.

Knight, W. B. (2006). E(Raced) bodies in and out of sight/cite/site. Journal of Social Theory in Art Education, 26, 323-345.

Kwet, M. (2019). Digital colonialism: US empire and the new imperialism in the global South. Race \& Class, 60(4), 3-26. https://doi.org/10.2139/ssrn.323 2297.

Martini, B. (2017, May 10). Decolonizing technology: A reading list. https://bea tricemartini.it/blog/decolonizing-technology-reading-list/.

Mignolo, W. (2000). Local histories/global designs: Coloniality, subaltern knowledges, and border thinking. Princeton University Press.

Mignolo, W. (2009). Epistemic disobedience, independent thought and decolonial freedom. Theory, Culture \& Society, 26(7-8), 159-181. https://doi.org/ $10.1177 / 0263276409349275$.

Nakamura, L., \& Chow-White, P. A. (Eds.). (2012). Race after the internet. Routledge.

Paul, C. (2003). Digital art. Thames \& Hudson. 
Quaintance, M. (2015, June). Right shift: Morgan Quaintance on the end of post-internet art. Art Monthly, 387, 5-8.

Quaranta, D. (2015). Situating post internet. In V. Catricalà (Ed.), Media art: Towards a definition in the age of technology (pp. 121-134). Gli Ori.

Rush, M. (2005). New media in art. Thames \& Hudson.

Sefa Dei, G. J., \& McDermott, M. (2014). Introduction to the politics of antiracism education: In search of strategies for transformative learning. In G. J. Sefa Dei \& M. McDermott (Eds.), Politics of anti-racism education: In search of strategies for transformative learning (pp. 1-11). Springer.

Shifman, L. (2014). Memes in digital culture. The MIT Press.

Simmons, X. (2019, July 2). Whiteness must undo itself to make way for the truly radical turn in contemporary culture. The Art Newspaper. https://www.the artnewspaper.com/comment/whitney-biennial-whiteness-must-undo-itself.

Smith, T. J. (2018). What might a post-internet art foundations course look like? FATE in Review, 36, 42-49.

Smith, T. J. (2020). Critically reframing post-internet art toward the future of art education curriculum. Art Education, 73(3), 38-44. https://doi.org/10. 1080/00043125.2020.1717821.

State of Broadband Report. (2019). International Telecommunication Union and United Nations Educational, Scientific and Cultural Organization.

Sundberg, J. (2014). Decolonizing posthumanist geographies. Cultural Geographies, 21(1), 33-47. https://doi.org/10.1177/1474474013486067.

Tavin, K. M. (2003). Wrestling with angels, searching for ghosts: Toward a critical pedagogy of visual culture. Studies in Art Education, 44(3), 197-233.

Tribe, M., \& Jana, R. (2006). New media art. Taschen.

Umoja Noble, S., \& Tynes, B. M. (Eds.). (2012). The intersectional internet: Race, sex, class, and culture online. Peter Lang.

Valentine, B. (2015, April 7). Where are the women of color in new media art? Hyperallergic. https://hyperallergic.com/195049/where-are-the-women-ofcolor-in-new-media-art.

Ward, T. (2011). Hegemony and the web: The struggle for hegemony in a digital age. In R. Rikowski (Ed.), Digitisation perspectives (pp. 147-166). Sense Publishers.

Wolfgang, C. N. (2019). The white supremacy of art education in the United States: My complicity and path toward reparation pedagogy. Journal of Cultural Research in Art Education, 36, 14-28.

Worlds \& Knowledges Otherwise. (2009, September 18). Volume 3, dossier 1: Decolonizing the digital/digital decolonization. https://globalstudies.trinity. duke.edu/projects/wko-digital-1. 
Open Access This chapter is licensed under the terms of the Creative Commons Attribution 4.0 International License (http://creativecommons.org/licenses/ by $/ 4.0 /$ ), which permits use, sharing, adaptation, distribution and reproduction in any medium or format, as long as you give appropriate credit to the original author(s) and the source, provide a link to the Creative Commons license and indicate if changes were made.

The images or other third party material in this chapter are included in the chapter's Creative Commons license, unless indicated otherwise in a credit line to the material. If material is not included in the chapter's Creative Commons license and your intended use is not permitted by statutory regulation or exceeds the permitted use, you will need to obtain permission directly from the copyright holder.

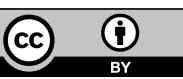

